\title{
THE POSITION OF PONTOPHILUS ECHINULATUS (M. SARS) IN THE CRANGONIDAE
}

\author{
By Marie V. Lebour, D.Sc. \\ The Plymouth Laboratory
}

On 26 November 1953 the new research ship Sarsia on her first cruise collected a number of Pontophilus echinulatus (M. Sars) (with an Agassiz trawl, depth 100 fm., La Chapelle, Bay of Biscay). Mr G. R. Forster, of the Plymouth Laboratory, noted that these did not fit into the key given by Kemp (I9IO) in that they have in the male a distinct appendix interna at the base of the four last pairs of pleopods, while in the female this is absent, the inner ramus being usually undivided, although occasionally an indistinct division can be made out. Otherwise they agree with Kemp's diagnosis.

Kemp (I9I0) notes M. Sars I86I as authority, but this is only a preliminary description. In Sars (I868), given in Kemp's (I9I0) bibliography but not under the species, it is seen that he describes both male and female exactly as in the specimens from Sarsia, the male having a distinct appendix interna on the last four pairs of pleopods and an appendix masculina also on the second pair, the female pleopods having very short inner rami, except in the first which is long, and there is no appendix interna. Sars's figures of these limbs are very good. Kemp (I9I I) joins Philocheras with Pontophilus, and in this he is now followed by most authors.

Kemp (I9I6) reviewed the pleopods in the genus Pontophilus, as far as he could with the material he had in India, and he proposed certain groups according to the presence or absence of the appendix interna. His material was deficient in males of some species, including $P$. echinulatus which he suggests would probably belong to group $\mathrm{V}$ in which the appendix interna is absent in both sexes.

This problem was referred to Dr I. Gordon, who very kindly examined some of the material in the British Museum and found that both male and female agreed with Sars's figures. She also found that most of Kemp's Irish Fisheries' material is immature, although one (Helga CXXI), presumably that at the foot of p. I45 in Kemp (I9IO), had an appendix interna on pleopods $2-5$, probably not noted by Kemp. Thus the immaturity of these Irish specimens accounts for the fact that P. echinulatus (as Philocheras) is placed among those species which have no appendix interna (Kemp, I9Io, pp. I35, I46).

As it is now certain that $P$. echinulatus has in the male a distinct appendix interna and none at all in the female, it follows that of the groups formed by 
Kemp P. echinulatus should be placed in group III in which are included his four new Indian species $P$. lowisi, $P$. pilorus, $P$. candidus and $P$. plebs. It is interesting to find that Holthuis (1952) describes the pleopods of $P$. prionolepis n.sp. exactly as in Sars's description of echinulatus. He states that $P$. prionolepis is closely related to $P$. lowisi Kemp which is in group III, thus emphasizing the probable correct position of $P$. echinulatus. However, $P$. sculptus (Bill) seems very close to echinulatus except for the pleopods. Kemp (I9II) revised his diagnosis of P. sculptus, and again in I9I6, as it was found to have an appendix interna on the last four pairs of pleopods in the male and on some of them in the female. In Kemp's (I9II) table, if we substitute the presence of an appendix interna instead of the absence in P. echinulatus, we see that echinulatus and sculptus agree in every other point. Kemp (I9I6) shows that the female sculptus has an appendix interna on the second and third pleopods and a rudimentary one on the fourth, thus differing from echinulatus, and therefore that species cannot be included in group II.

It follows from the above notes that $P$. echinulatus should take a different position and no longer be classified with $P$. bispinosus and $P$. trispinosus, if the appendix interna is as important in showing relationship as Kemp suggests. $P$. echinulatus does not fit into group II and must, if placed in any of the groups, be included in group III with Kemp's four Indian and Holthuis's African species, none of which appear to be so near it as do P. sculptus, $P$. bispinosus and $P$. trispinosus. Except for the appendix interna, P. echinulatus seems to agree very well with these species.

The best one can do at present seems to be to keep Kemp's groups I-V, emphasizing the fact that $P$. echinulatus seems to be nearest $P$. sculptus, $P$. bispinosus and $P$. trispinosus, although these are in different groups.

Group I (with appendix interna in both sexes).

Group II (with appendix interna in $\sigma^{\hat{t}}$ and partly in ): $P$. sculptus, etc.

Group III (with appendix interna in on only): P. echinulatus, etc.

Groups IV and V (no appendix interna): P. bispinosus, $P$. trispinosus, etc.

\section{REFERENCES}

Holthuis, L. B., I952. Crustaces decapodes, Macrures. Résult. sci. Expéd. océanogr. Belge dans l'Atlantique sud (1948-49). Vol. 3, Fasc. 2, 88 pp.

Kemp, S., I9I0. The Decapoda Natantia of the coasts of Ireland. Sci. Invest. Fish. Br. Ire., I908, No. I, I90 pp.

- IgIr. Notes on Decapoda in the Indian Museum. II. Description of two new Crangonidae with observations on the mutual affinities of the genera Pontophilus and Philocheras. Rec. Indian Mus., Vol. 6, pp. 5-I2.

- 1916. Notes on Crustacea Decapoda in the Indian Museum. VI. Indian Crangonidae. Rec. Indian Mus., Vol. I2, pp. 355-384.

SARS, M., I86I. Bemerkongen om Crangonidae. Forh. VidenskSelsk. Krist., Aar I86I, pp. I79-187. [Not seen.]

- I868. Bidrag til kundskab om Christiania-Fjordens Fauna, Crustacea. Nyt Mag. Naturv., Bd I5, 104 pp. 